\title{
Social Structures, Gender Dimensions and Semantic Implications in Dance: The Sergiani Custom in the Village of Megala Kalivia (Trikala)
}

\section{Konstantinos Dimopoulos}

Phd Student, School of Physical Education and Sport Science, National and Kapodistrian University of Athens

\section{Vasiliki Tyrovola}

Emeritus Professor, School of Physical Education and Sport Science, National and Kapodistrian University of Athens

Maria Koutsouba

Associate Professor, School of Physical Education and Sport Science, National and Kapodistrian University of Athens

Doi: $10.1515 / \mathrm{mjss}-2017-0006$

\begin{abstract}
Throughout the world there are rites and customs that take place in the context of a specific time and place. The dance act is a reflection of the local society, as it represents a way of validating or questioning the local structures, interpersonal and gender relations, as well as the community policies. Such custom would be the custom of sergiani in the community of Megala Kalyvia (Trikala). The aim of this paper is to examine the custom of sergiani and the role of the dance in that community. The collection and processing of data is based on the principles of ethnographic study. In order to examine the form of the dance, the structural-morphological model is used, while the dances were notated using the Labanotation system. The interpretation of the dance is based on the methodological optics as established by Hanna (1988), according to whom, in order to reach conclusions regarding the society and gender relations, dance must be taken into account. By controlling the patriarchal sovereignty in that community, the female gender would always find mechanisms to show resistance and renegotiate women's role, position and relation not only against the opposite sex, but also within women. Those mechanisms are triggered through customary and dance practices, such as the sergiani custom.
\end{abstract}

Keywords: dance, gender, gender relations, social practices, social structures

\section{Introduction}

Throughout the world there are rites and customs that take place in the context of a specific time and place, for a specific purpose and they serve various functions. Specifically, various customs with a strong religious and ritual character are observed during Easter time or other religious festivities. These customs are accompanied by dances, which are either the core of the ritualistic procedure or in certain cases they function as a frame for said procedures. They are performed only on that specific day or period and they are used for specific functions and purposes of the community. The dance act is a reflection of the local society, as it represents a way of validating or questioning the local structures, interpersonal and gender relations, as well as the community policies. Such custom would be the custom of sergiani in the community of Megala Kalyvia (Trikala). 
The review of the relevant literature shows that various researchers have already dealt with the custom of sergiani. (Aggelis, 1987; Athanasiou-Dimopoulou, 2012; Kolonas, 2014; Magouliotis, 2010; Rousiakis 2006; Tziamourtas, 2003; Tziamourtas, 2006). However, till now researchers have only made a mere reference the custom, focusing their attention on the time period (when), place (where) and the participants, with only a few exceptions ${ }^{1}$, without proceeding to any kind of analysis or interpretation of their data.

However, a completely different approach and analysis of the sergiani custom is attempted by Dimopoulos (2012), having three villages in Karditsa as his research field. Dimopoulos examines the custom and the dances performed during that specific customary procedure, he refers to their

${ }^{1}$ From an etymological point of view, sergiani means stroll. It comes from the Turkish word sevran which means excursion, while the related verb means "stroll, ramble, saunter" (according to Greek language dictionary Tegopoulos-Fytrakis, 1990:685). Tziamourtas (2006), analyses the etymology of the word sergiani in one of his studies, as well as the concept of sergiani from an ethnological point of view. In summary, he mentions the

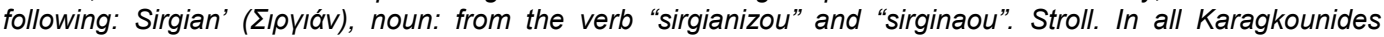
villages, women used to gather in an open space and they would hold hand by hand (approximately 20 women danced in a slow and slinky pace singing with their own voices. Men used to stroll around, some of the sitting and enjoying the spectacle. Little kids would play around cheerfully. That was the place where "bride picking" would take place. Sergiani was held on Epiphany Day, during Carnival, at Easter time..." (p. 412). Rousiakis (2006) states the following: "the whole village gathered in the village square and watched the women dancing. This gathering was known as sirgian', a term which was also used in general by the people of the village to refer to any public social event containing dance performance..." (p. 511). As for the custom, as well as the time and place of its performance, many researchers have dealt with it and in various communities. Regarding Easter time, Aggelis (1987) mentions that "...in all Karagkounides villages of the Thesssalian valley and during the afternoon of the third day of Easter, the whole village gathered at the chorostasi (place reserved for dancing), man would start to dance, certainly separately from women, to the sound of folk songs until the sun went down..." (p.126). Tziamourtas (2003), referring in general terms to sergiani, mentions that "during Carnival time, "...in the afternoon, during sergiani, where women would dance and sing..." (p.249) and during Easter time the devotional mass of Love in the church and "...after it finished, all would go to the sergiani, where they would watch Easter dances, danced by women of the Karagkounides ethnic group, accompanied by cheerful songs. On the second and third day of Easter, another Easter mass took place, including egg-tapping custom (typical in Greek Easter) and dances in the chorostasi (place reserved for dancing)..." (p. 271). Kolonas (2014) also makes a general reference to sergiani: he mentions that "during Carnival day, and before entering the Great Lent period (Sarakosti, in Greek), during which no wedding, dances or celebrations were allowed, they felt the need to enjoy themselves, sing and dance. After the first week of the Triodion period, which is also known as the "free" week, everything was allowed, whereas during the second week, which is also known as "meat" week, there were jokes, dances and songs..."(pp.45-46). Regarding the Easter sergiani, the same researcher states that "...during the afternoon of the same day (Easter Sunday), the Karagkounides group went back to the church in order to attend the devotional procession of Love. After it finished, they all went to the sergiani, where Easter dances were cheerfully performed by women belonging to the Karagkounides group. On the second and third day of Easter, another Easter Holy Mass took place, including egg tapping and dances [...]. Therefore, according to these traditional customs, the whole setting of that day comprised the Holy Mass followed by the sergiani, during which women would dance and sing Easter songs..." (pp.47-48). Magouliotis (2010) states the following regarding the Carnival sergiani in the municipality of Agnantero (Karditsa): "Finally, early in the afternoon (on Epiphany Day), most of the people would go to Touloumpa, to the Fountain in the Square (Vrysi stin Plateia), to celebrate, watch, and sing the songs of the women which would dance the established dances. The same songs were also present in the neighbourhoods during Saturday nights, particularly when the moon was bright and the weather was good. This would happen almost on every Sunday, festivity and Saturday night till Carnival time" (p. 106). The same researcher (2010) states the following regarding the Easter sergiani: "....Therefore, on the second day of Easter, after the priest coming out of the ksiostri (exit) of the church, and after exchanging wishes, then middle-aged women, newly married and unmarried women starting holding hand by hand and formed a circle almost in front of the entrance by the temple, and they would go dancing and singing up to the spot t' Argastiri. This is dated in around 1910. In the following years they would move the dance to the square, after they gathered there first..." (p. 161). According to Athanasiou-Dimopoulou (2012), sergiani "... was a way of entertainment and bride-picking enjoyed by simple village people until the 60's, when it started to fade [...]. After the mass would end, they went to the village square and exclusively women would hold hand by hand and started dancing. Men used to sit at the village bar or remain standing and enjoying the view of women dancing. Children would play around and between the dancing women..." (p. 84). 
sequence and performs a labanotation of the dances. He also analyses the structure and form of the dances, while he examines the way gender roles are reflected and gender relations are shaped through the customary practice of sergiani and the practice of dance. He distinguishes between time periods of performance regarding the custom: the first period is the Carnival period, which starts on Epiphany Day and ends on Carnival Sunday (Dimopoulos, 2010, Dimopoulos, 2012:150).

The second period corresponds to the Easter period, according to the researcher (2012), which starts on the first day of Easter (Easter Sunday) and ends on the third day of Easter (Easter Tuesday). From the above we can conclude that the research of Dimopoulos deals with the three communities, while the research field does not comprise Megala Kalyvia (belonging to the province of Trikala). Therefore, up to this date, no extensive reference or substantive study has been made on the dances, their role and their function within the framework of the custom and regarding the community of Megala Kalyvia ${ }^{2}$.On the other hand, there is a complete lack of studies regarding gender roles and gender relations as they are reflected and shaped through dance performance in that community, during the ritual procedure of the custom.

This gap is now covered by this study, which focuses on the dance repertoire and the dances of sergiani in Megala Kalyvia (Trikala), using those as analytical and hermeneutical tools to answer to the following questions: what did sergiani custom mean for the people of Megala Kalyvia? Which were the scopes and purposes of the custom within the local community? Did it function as a space of configuration and negotiation of gender roles and relations? And if so, in which way?

The aim of this paper is to examine the custom of sergiani and the role of the dance in the community of Megala Kalyvia (Trikala). In concrete, this papers aims to focus on the way and the own reason of its performance, through the analysis of the dance repertoire and the dance contained in it. From another point of view, it also focuses on the role and functionality of the dance while perceiving the custom and the dance as a dance event and space of negotiation and configuration of interpersonal and gender relations.

\section{Methodological Approach}

The collection and processing of data is based on the principles of ethnographic study and derives from primary and secondary sources (Buckland, 1999;Giurchescu, 1999; Crang, \&Cook, 2007; Robson, 2007; Sklar, 1991, Gkefou-Madianou 1999; Lydaki, 2001). Primary sources refer to the data coming from in-situ research, through interviews (open-type questions for semi-structured interview and unstructured interview), and the participant observation combined with simultaneous audio and video recording of the inhabitants of the community. As for participant observation, qualitative method was used in a small-scale research to specific persons that were chosen as the "informants" based on their age and indigenousness (Cohen, 1985, Bernand, 1994, GkefouMadianou, 1999). In addition, the data collected during interviews was collated with data that was already available in written texts. Data collation between written sources and interviews represents a wig-wag movement between historicaldocumentation and testimonies from the present, which

\footnotetext{
${ }^{2}$ Rousiakis (2006) has also made reference to the custom and the dances of sergiani in the municipality of Megala Kalyvia. According to him, "...winter dances of the women were performed during the time period from Epiphany till the last Carnival Sunday...[...]... Only women participated, which would hold hand by hand and always in the form of a dance circle. They accompanied their dance with their own voices and songs, sung by them without any musical instruments accompanying..." (p. 511). Moreover, he makes reference to the place where the sergiani took place, as well as the songs and the dance participants. Regarding the sergiani dances, he states that "... dances were executed in a slow pace and they had 3 BDM (Basic Dance Motifs -in greek $B X M)$. The BDM to be performed in each song was decided by the first one, the one who led the dance, followed by the other women. Specifically, only two songs had BDM..." (pp.511 and 512). As for the Easter sergiani, he states that "...Easter women dances were performed during three days: Easter Sunday, Monday, and Tuesday. On Easter Sunday [...] people headed from to the church to the square. There, women would dance and sing their Easter songs without any musical accompaniment..." (p. 551). Finally, regarding the dances in Easter sergiani, he mentions that "...BXM, the hand-holding method, the participation and sequence of the women within the dance circle, the whole dance performance was the same as the one in the winter dances..." (p. 515)
} 
finally leads to the restitution of a fragmentary traveller reference and may offer an objective historical testimony (Nestoros-Kyriakidou, 1993). Finally, the liability and validity check of the in-situ data was performed using the technique of the "information saturation" (Bertaux, 1981). Secondary sources refer to the review and use of the existing literature and was based on the principles of archival ethnography (Gkefou-Madianou, 1999) and historical research (Adshead \& Layton ([1983]1988). In order to examine the form of the dance, the structural-morphological model is used (Tyrovola, 1994, 2001, 2013) while the dances were notated using the Labanotation system (Bartenieff, 1984; Benesh, \&Benesh, 1977; Farnell, 1999; Hutchinshon-Guest, 1984; JohnsonJones, 1999; Lange, 1976; Page, 1996; vanZile, 1985/1986; vanZile, 1999; Koutsouba, 2005).

The strategy used regarding analysis and interpretation follows the "new" ethnography or "postmodern" ethnography model according to Tyler theory (1986) and refers to the direction of the "bi-objective" (Rabinow, 1977) or "dialogical" (Dwyer, 1982) ethnography focused on reflection, combined with the hermeneutical model of the "thick description" of Geertz ([1973]2003). According to the model of "thick description", the anthropological writings and relevant are themselves interpretation of the culture under examination. The interpretation of the dance is based on the methodological optics and analytical practice as established by Hanna (1988), according to whom, in order to reach conclusions regarding the society and gender relations, dance and dance practices must be taken into account, since they are fields of designation and management of gender relations and local social structures. Furthermore, the Schwaiger methodological optics (2012) is used in this study, according to which gender identities are a product and a result of social procedures related with the social class, age and dance performances.

\section{Megala Kalyvia (Trikala). The Place and the People}

The village of Megala Kalyvia lies in the lowland region of Trikala, and precisely, in the southwest part of the region. It used to be the administrative centre of the community named after the village under Kapodistrias, whereas it now belongs to the municipality of Trikala city. It is $8 \mathrm{~km}$ away from the city of Trikala and it is the last community before reaching the province of Karditsa. With a population of 1.849 inhabitants (according to the census of 2011) is therefore, the frontier village between the provinces of Trikala and Karditsa.

Its initial name was Kalyvia. In the beginning of the 19th century, there used to be several settlements, (Chiotis, 1997:13). The definition "Megala" (Great) appears to have been introduced at a later stage, when all above settlements were unified, apparently around 1810. The name "Kalyvia" is documented for the last time in 1838. According to earlier oral narrations of two locals, F.Papanikolaou (1881-1967) and P. Karalis (1892-1967), “...Mpeis, the representative of Ali Pasha of loannina, asked the Kotsampasis ${ }^{3}$ (local Christinan notable) how they could create a big village such as Megalos Palamas in Karditsa. The Kostsampasis replied that that would be possible by unifying all above settlements..." (Chiotis, 1997:21). Hence, around 1810 all settlements were unified and the community was renamed to Megala Kalyvia.

The inhabitants of Megala Kalyvia belong to the ethnic group of Karagkounides. Their main activity is mostly agriculture, while animal husbandry is mainly used to satisfy family needs. Mixing with other populations was rather scarce. The "foreign" elements appear to arrive mostly after 1900, and they came mainly for Karagkounides communities.

\section{The Custom of Sergiani in the Community of Megala Kalyvia (Trikala)}

\subsection{The custom of sergiani from Epiphany Day to Carnival Sunday.}

The custom of sergiani belongs to the category of customary circumstances, and it is an exclusivity of the female gender, belonging to the rituals. Therefore, it can be defined as a predetermined, recurrent and symbolic activity or practice that includes dance, song and other expressive means,

${ }^{3}$ Kotsampasis: it comes from the Turkish word kocabașı (koca = great, big, old + baș $=$ head, first). They were the local Cristian notables, on a province level, during Ottoman period. 
either verbal or non-verbal. In this case, the ritual includes symbolic acts and practices which refer to the space of the "sacred time", as opposed to the space of "profane time" (everyday life) (Douglas, 1966; Leach, 1976).

The Carnival sergiani lasts from Epiphany Day till the last Carnival Sunday. In earlier times, women would dance every Sunday. In the morning, they went to the church and after mass would finish, they danced on the churchyard. They also danced during the afternoon, not only on the churchyard but also in the central square of the village. This whole customary process was called sergiani. According to Sofia, "...we danced every Sunday, we went to the church in the morning, we danced on the churchyard and later in the afternoon in the square...". As Zoi mentions... "...from Epiphany day to Carnival time, every Sunday afternoon. Every Sunday afternoon in the square, women sang, danced...". According to Sofia, "....when it was 2 o'clock, we would check out to see if anyone of us would be going out, and we looked, and we saw other going out, and we could go out as well, we dressed up and went out..." and the process would finish in the afternoon, because the day was short due to wintertime. Sofia adds that "...when it went dark, we were wondering whether to sing another song. Well, now, just the last one and we're off...".

Apart from the Sundays and Carnival Sunday, women also gathered during other days. As Sofia mentions, "...after Epiphany Day, five or six of us girls gathered at night, it was already dark, and we sang, the typical Carnival songs. In the neighbourhood, every neighbourhood, We went out to sing...", whereas Vasiliki K. adds "...even though it was cold...." Therefore, in addition to the established day (Sunday), women could gather any other day and perform the custom of sergiani. A non-formal, casual sergiani, within the framework of the neighbourhood, with a more familiar, closed and a less ritual character.

Hence, we can observe two different types of sergiani on that specific period, which also connect with the bipoles "public"- "private" and "informal"/"familiar"- "formal"/"ritual". The timespace in the public space of the church and the square was strictly specified and confined, this meaning that the sergiani custom took place every Sunday and at a specific time (morning after the mass and afternoon), in such a way that it had the character of a custom, a sacred procedure, as well as "....in the ceremony, that is, the established behaviour, creates the feeling that religious convictions are real and religious commands are valid..." (Geertz, 2003:118).

In the custom of sergiani placed in the "sacred time" rituals, dance is inextricably connected with time and space, as "...dance can only be perceived only in this specific time-place framework. It exists only in connection with the specific place and can be performed only during that specific time..." (Nitsiakos, 2003: 106). However, aside from the production and reproduction of beliefs, convictions and knowledge, sergiani also created an atmosphere of devoutness and seriousness, together with a feeling of emotional charge. In any case, sergiani, as a ritual, "...is done collectively, by a number of persons feeling the same emotion. ..." (Harrison, 2006: 32). On the contrary, within the private space, in the neighbourhood, women gathered any day they wanted and whenever they had time for sergiani. Within that context, sergiani had a more informal character and did not have a customary character, as it was not repeated in a specific space-time context; it was rather random, taking place in a space-time context the same women would choose. Certainly, we have to confirm that this procedure is also included in the wider framework of the custom, as it can only take place strictly form Epiphany Day to Carnival Sunday, and not in another random time period. Hence, we are dealing with "... a stereotypical act..." (Harrison, 2006: 24), a characteristic feature of every "sacred" ritual. It is sacred because, firstly, it has a religious nature (it takes place on the churchyard), and, secondly, it refers to established behaviours, "...that are claimed, controlled and repeated in a specific circumstance..." (Pouchner, 2009:190, 191).

Participation in the sergiani costume was a purely female business. According to Paraskevi, "... men didn't dance during Carnival [...], us women danced to our own songs [...] where the school was and around the school yard railings, young men would pick their future wife, it was really nice [...], all men were standing around the railings...". Margarita also adds, "...no men. There was no place for men to dance in the square during Easter and Carnival...]. Moreover, Vasiliki X. mentions that "...men would not go out a lot, for a dance, there were just women dancing and singing...", whereas Zoi states that "...men did go out, but they would not dance, women did their own songs, those dance was done with singing, they used to sing their own songs. Women 
went out and started the dance. Men were around them watching. But they wouldn't dance...] Efthimios also confirms that "...us men were mere spectators. We used to go watch and see if we there was any girl we liked and wanted to marry her...".

The order in which women would position themselves in the dance circle was specific and strictly defined, following set hierarchy in a faithful way. Zoi states that "...the first ones to join the dance were the elderly women and, then, by order, as they were placed in the space. When they formed the circle, first went the women that were married the longest and according to their age, everybody knew where her place was: elderly women on the front, then engaged women, then young unmarried girls...". As Paraskevi mentions, "...the order was like this: third-age women, then middle-aged women, then newly married women and engaged girls. Unmarried girls did not dance, there was a wide "bride picking" going on, boys on one side and girls on the other. Single girls didn't dance, but engaged girls did. This order was really great!..." In this respect, Vasiliki X. adds that "... first went the middle-aged women ${ }^{4}$, that is how we called them, they led the circle dance..."

Therefore, hierarchy depended on the social status of the dancing woman and not so much on her age. The order in which they joined the dance circle was according to the length of her marriage rather than her age. Vasiliki X. gives an example in order to shed some light on this issue: "...they know where their place was. Yesterday Sunday Sofia got married, and then next Sunday I got married, so I will go after Sofia, age has nothing to do with this, the important factor was the wedding and engagement date...", and Sofia validates this example by saying "...[according to] when we got married". Another factor was also friendships and social interactions among participating women, according to what Vasiliki $X$ confirms: "let me also tell you this thing, friend groups also mattered. For example, I was with a friend from my neighbourhood and we wanted to dance next to each other...". Therefore, even within the strict hierarchy of the circle structure, friendship was also taken into account (which is completely normal), though always under the strict rules imposed by the custom as well as the age and social status hierarchy. This differentiation was also visible through their dress code, as each group (elderly women, married women, engaged women) had different dresses.

According to Vasiliki X, "...all elderly women wore different clothes. They made their mpourmpoulia ${ }^{5}$ knots on their kerchief, they wore folded sleeves, they used to put it like this on the front, and then the others would not wear their mperetes ${ }^{6}$ with golden-plated coin, then they put their knots on, because those are three different things, and then went the brides, and then the girls...".From the above it can be understood that dressing was a code and an indicator of the position of the women in the circle of sergiani. According to what she wore, which was a combination of factors of age and social status, the woman knew where to place herself within the circle of sergiani dance.

The sergiani custom, apart from dance and entertainment "place" was also a "place" where matchmaking took place. The candidate bride was picked during the customary procedure, as single women had no other chances to get out of the house into the public space, so that candidate grooms could get to meet them. The sergiani dance was a limited and supervised space, subject to social control, where the future wife was chosen. At the same time, it was a form of socialization and integration of the single girls into the local society. It was a procedure of integration of the girls into the female society under their status of candidate bride. However, the main spectators that judged the girl's ability to become a future bride were the candidate parents-in-law, who arranged their children's marriage with the other parents-in-law.

According to what Paraskevi reveals, "...in this order, men, boys, girls all dressed in their white kerchiefs, and they picked [...]. And also mothers, grandmothers, all of them, they would watch that girl and they would say, oh well, she is fine for our boy, let's take her. All was peaceful during the sergiani bride-picking....". Sofia would add that "...this is where matchmaking took place, it was really nice, they could see the bride. Cause we were not allowed to go to the village bar, no

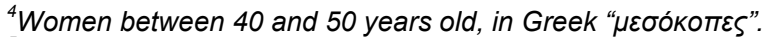

${ }^{5}$ Mpourmpouli: way of tying the kerchief for elderly women belonging to the Karagkounides ethnic group.

${ }^{6}$ Mpereta: this is how they used to call the bridely kerchief of the women belonging to the Karagkounides ethnic group in Megala Kalyvia.
} 
girl entered there in any circumstances [...]. Women had their own sergiani...".

All sergiani dances were danced without any musical instruments accompaniment, there were just songs. Song was based on antiphony: the singing was initiated by the first ones in the circle till the middle (the first half, which were the more experienced ones) and the same singing was repeated by the second half (who did not know the song and were in process of learning it or barely knew it). Paraskevi states, "...all with the mouth..." and Margarita completes: "...look, they were just five songs, first sang by the first half, and then by the other half and so time passed by. They repeated it, first the elderly ones on the front and then the youngest ones on the back. Then there were many sycamores which would echo this fuss of women voices, lively voices...". The content of

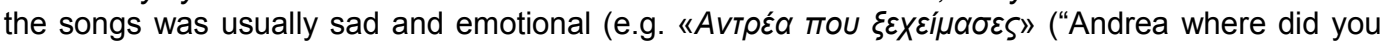

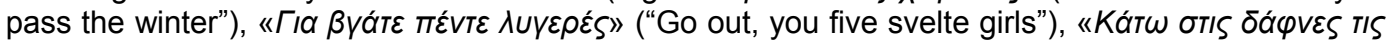

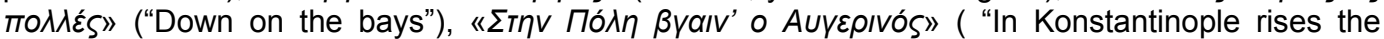

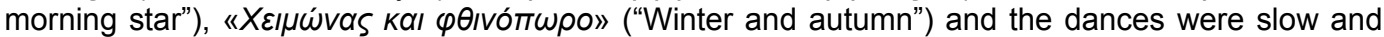
"heavy".

In conclusion, from the above testimonies it appears that in Megala Kalyvia, from Epiphany Day to Carnival Sunday, women were the rulers of sergiani and dance practices. On the eve of every festivity, they went out to their neighbourhoods and sang songs without any musical instruments accompaniment. Men, if and when they wished, entertained themselves in the bars of the village by listening to the gramophone or enjoying live music (rarely).

As opposed to lowland communities of Karditsa, where in many cases men used to entertain themselves on Sundays with the accompaniment of musical instruments (Dimopoulos, 2012), in that specific community no such thing occurred. Men hardly participated, but they were present to "control" the social behaviour of their wives and daughters or to participate in the matchmaking process taking place during the sergiani custom.

The dance event that corresponds to the ritual period from Epiphany Day to Carnival Sunday (festive-customary circumstance) incorporates symbols and practices having as a point of reference the roles and the relations between genders. The view of the inhabitants of Megala Kalyvia about their past and their relations with the past are a main component of the meanings of the dance event and the interpretation given to the sergiani custom. We could affirm that the participants make full use of the symbolical definers of the genders that are integrated into their dance practices. The variety of their narrations, although they seem to merely describe the dance event, in essence they compose the very own dance event.

This means that informants unconsciously equate the dimension between the "public" and "private" space, since through their narrations on the dance event they reflect the public character of their dance performances, which also take place within the limits of an exclusively female collective space, the neighbourhood. According to the survey data, it is confirmed that women not only take part in public social practices, such as dancing and singing, but they also do this without the presence of men. This fact questions the consolidated perception according to which the woman is only confined in the private space of the house or gets out into the public space only accompanied by the man or under her unequal and submissive position against the man. On the contrary, it brings a different image to the surface according to which the woman is presented as a dynamic active subject and the social dynamics is proven by the fact that it creates social conventions other than the existing ones in other regions of Greece.

Those are social conventions where the female gender seems to be acting on her own without the "authority" of men. Those are one of the few cases where women dance and sing on their own for such a long time period, without the presence of men. Thus, this period is also defined by the exclusively female participation in social-dance practices with the exception of men participating some days.

\subsection{Dance events during Easter period}

In the whole region of Thessaly, we can observe various dance activities. In lowland communities composed of Karagkounides ethnic group, such as Carnival and Easter, we observe the sergiani custom (Dimopoulos, 2012). Likewise, in the community of Megala Kalyvia, which belongs to the 
same geographical and cultural context (Karagkounides), the same custom takes place. The dance events of that festive period, as in other communities of Karagkounides (Dimopoulos, 2012) include dances and songs that are sung exclusively during that period.

Formerly, until the decade of 1960 and during the Easter period, they danced during three days, from the day of Easter Sunday till the third day of Easter (Tuesday). According to Margarita, "... Sunday, Monday and Tuesday..." whereas Sofia mentions that "...three days during the morning and the afternoon, we went to the church in the morning and to the square in the afternoon. Then, the second day, and then the third day, always dancing!..." Zoi adds that women would go "...in the afternoon on the first day, in the afternoon also the second day, unless it was St. George's Day. In that case, they would go to the church in the morning, and when the mass would end, they danced on the churchyard, and then in the afternoon, they went first to the square, they would dance there, and then to the church and then to the square once again. And on the third day, they did both morning and afternoon. In the afternoon they had a good time in the square and in the morning they danced in Kapsouda ${ }^{7}$. This is where they went in the morning, whereas in the afternoon they would go to the square...".

The motif of the custom of Easter sergiani was the same as the Carnival one. Women perform the customary practice both during the morning and the afternoon, as it occurs during Carnival period. Likewise, they danced in front of the church in the morning and in the square in the afternoon. Therefore, we can certainly notice a resemblance in the way of performing the custom. During Easter period, there was no sergiani performance within the family or neighbourhood context, as opposed to the Carnival period. This might be due to the fact that the Easter sergiani performance period was shorter, only three days, during which women performed the custom in the public space of the churchyard or the main square. Finally, dances of that period are exactly the same, structure-wise, with the ones performed during Carnival period. Nevertheless, songs during Easter sergiani were different that the ones of the Carnival sergiani. According to Sofia's testimony, they were "...other songs...", while Margarita adds that there were "...different songs for Easter, different songs for Carnival, no connection at all between them...". Zoi comes to agree as well, who informs that "...no, songs were different...". According to Paraskevi, "... in Easter we would sing to celebrate the arrival of Easter...". Aside from the differences regarding structure and morphology of the songs, the way of singing those was also different. According to Vasiliki X, "...they had a different sound...". Although the sound and the songs were different, the way of dancing those songs was exactly the same as the one used for Carnival period songs. Margarita affirms, to this respect, that they had "...almost the same pace...", whereas Sofia adds that "...they had the same style, although the sound changed, as did the songs and the lyrics...", while Margarita states that "...the paces were the same ones and with the same slow rhythm...".

The termination of the Easter sergiani was defined by the return of the shepherds from their pasture tasks. They had their cattle on the prairies ("...we used to take them up onto the prairies...", as Sofia testifies, and according to Paraskevi, "...each one went to this home..."). Vasiliki K. states that "...as soon as the pack set off, the cattle, the cows, we would get back home..." Sofia adds that as soon as the cattle arrived, "...women would rush back home, to go for the cows", or "tie the cows up, when the pack left and elderly women on the back to tie the cows up...", according to Vasiliki K. Margarita affirms, showing her wrist as if she had a watch, "...that was the time, the cattle is back [...], they had to leave..." and Sofia adds "...the dance broke down...". However this would only occur during Easter sergiani as during Carnival period, cattle was closed into the stables, and as Sofia mentions expressly, "...during Carnival time, we had them closed into the stables...".

From the above it is concluded that Easter sergiani included three days of dancing. Specifically, Easter sergiani was the same as the Carnival one, regarding the time and place of performance. Easter sergiani as well as the Carnival one, was performed twice a day, once during the morning, after mass, and once during the afternoon on the village square. Dance is practically the same one, with the same slow-paced, "heavy", ritual movements, as it is danced also during the Carnival dances. The difference lies in the fact that songs are different, as well as the way of

\footnotetext{
${ }^{7}$ Kapsouda: area where sergiani was held, near the church.
} 
singing, their "sound" as defined by the locals.

The performance of Easter sergiani and the dances featuring this custom are also a female business. Women dance without the accompaniment of musical instruments, using exclusively their own voice. The thematic content of the songs refers to Easter and festivities of the season, songs

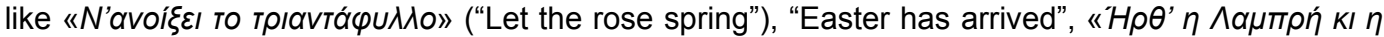

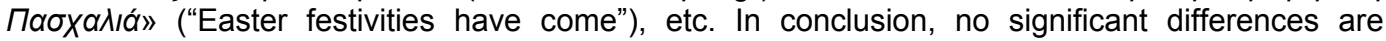
observed between Carnival and Easter customs of sergiani.

Table 1: Similarities and differences between Carnival sergianiand Easter sergiani

\begin{tabular}{|l|l|l|}
\hline Custom & Carnival sergiani & Easter sergiani \\
\hline Time of performance & Morning and afternoon & Morning and afternoon \\
\hline Dance & Slow, solemn, ritual & Slow, solemn, ritual \\
\hline Song & Mournful content & Easter content, festive and different type of execution \\
\hline Gender structures & Exclusive female participation & Exclusive female participation \\
\hline
\end{tabular}

From the above table we can conclude that Easter sergiani had almost the same structure and function with the Carnival one. The only difference is the fact that songs are different, both regarding their content and their way of execution. Both customs (Carnival and Easter one) are performed exclusively by women. This fact designates the female dynamics and their public presence in the customary circumstances of the community, as it was considered that they were the ones to deal with "women" issues, such as the religion and the rites.

Through her actions in the dance and customary circumstances of Carnival and Easter, the woman "takes control of her life", although without questioning the male authority in its very essence. She exposes herself into the public sphere through her dance, in the context of a public space that traditionally is identified with the male presence and power, setting aside, at least apparently, the male "omnipotence" and defining her own gender rules within the "game" of gender relations. It could be affirmed that the woman appears to be questioning the patriarchal structure of the local society. She makes her presence noticed and gets dynamically into the "game" of transformation and reconstruction of gender relations. However, her public presence does not bring the subversion of the patriarchal society, since the performance of sergiani and her active participation in this custom take place under the consent or permission of the man, husband, father of father-in-law. Thus, despite the fact that the woman is the main person in the sergiani performance, however, the presence of the man as a spectator/observer validates in a symbolic level, either directly or indirectly, the male authority in all its forms.

Moreover, the custom of sergiani serves as an initiation of the woman into a new world and represents a change of her social status, since she is now allowed to take part in it after her integration into a specific social status, such as the sphere of the married ones, the sphere of the engaged ones, or the sphere or the ones having the right age to get engaged. In other words, she leaves her past life behind, the life of a girl, and through the sergiani custom she is initiated into a new different world. The process of initiation is defined and marked by this specific ritual, which initiates her into the world of married women are women that are about to get married. Them joining the back of the circle and repeating the same verses already sung by elderly women, dancing in the same circle as those do marks their initiation into their world, leaving their "girly" life behind.

The initiation into this world is done by means of imitation, which is a characteristic and necessary element of the sergiani custom, as a ritual, "... as ritual involves imitation..." (Harrison, 2006:24). This imitation gave this Karagkouna (woman of the Karagkounides ethnic group) a position in the dance circle, but also in the social circle. From that moment, she was able to go out for sergiani and state her presence in the social life of the community, but also within the public space of the church or the square. This fact gives more emotional charge to the custom of sergiani, but also the sergiani as a concept, creating emotions for the girl, that is now "grown up" and mature, but also for the direct family members, while watching their girl, the girl of the family, the girl of their house, growing up and moving into a new social status. Therefore, sergiani custom as a ritual "...desires to recreate an emotion..." (Harrison, 2006:24). For the woman, as she passes from 
childhood to young age and maturity, the number of the dances performed increases, as does her social status.

As aptly stated by Harrison (2006), when referring to primitive civilisations, "it is strange to us to learn that among savages, as a man passes from childhood to youth, from youth to mature manhood, so the number of his "dances" increase, and the number of these "dances" is the measure pari passu of his social importance..." (p. 28).Therefore, the sergiani custom was an initiation ritual of the girls and as "...initiation rites are means for the establishment of sexual identity ..." (Geertz, 2003: 96), likewise the sergiani custom served as a statement and confirmation of the girls' identity. The younger ones would leave their "girl" identity behind and, through the ritual of sergiani they obtained their new identity, the one of the woman stating that she was married, engaged or had reached the marriage age.

\section{Notation of the sergiani dance in the community of Megala Kalyvia}

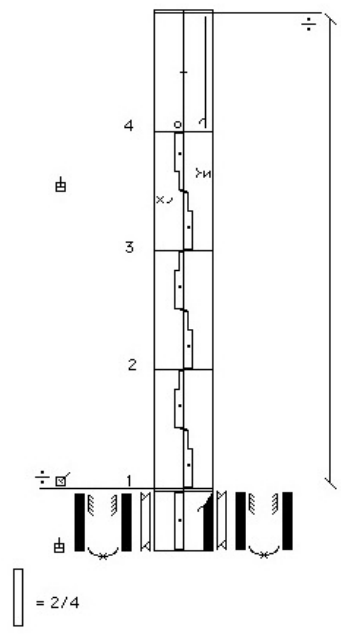

Typology and codification of the sergiani dance in the community of Megala Kalyvia

\begin{tabular}{|l|}
\hline \multicolumn{3}{|c|}{ The dance sergiani in the community of Megala Kalyvia } \\
\hline 4/4, Women, \\
$* \delta=$ right foot, $\alpha=$ left foot, $\mathrm{M}=$ holding hands down \\
$* * \delta_{14}=$ rise of the right foot, with the heel touching the ground. \\
$* * *$ The musical measure is under convention, because the dance sergiani, due to the fact \\
that is sung, women stopped and begun according to their breath.
\end{tabular}

\section{Conclusions}

Based on the above, various conclusions can be reached regarding the custom of sergiani its own structure as well as the social structures in the community of Megala Kalyvia, the gender relations in it, but also conclusions regarding the dances and their function within the rite of sergiani. It is a custom defined by a very strict structure and an intense religiousness.

Within the context of the sergiani custom, female gender had its leading role, since it was women who exclusively participated in the custom, dance and singing. Only women would dance, and what is more, according to a strict order and hierarchy, as imposed by the strict family and 
social structure of the community of Megala Kalyvia. The front positions of the dance circle were reserved for the elderly women, followed by middle-age women, then married women, and, finally engaged girls and girls having reached the marriage age. That order also reflected the social structure of the community. Elderly women were also the "leaders" in family life, enjoying many more rights and social recognition not only by women but also by men, who were mere observers in the case of sergiani custom. Therefore, elderly women had the control of the sergiani. They were the ones that would first start dancing, confirming in this way their leading role over married and single women that did not still have so many rights and social recognition and acceptance, so they had to depend on elderly women, and more specifically on mothers-in-law, both during dance and everyday life. In some way, the custom of sergiani was the mirror of everyday social structure of the community, where younger women and married women were recessive and followed the elderly ones.

Moreover, the sergiani custom was the place where married women learned from the elderly ones, following them in dance and singing. This carried a sense of preparation, as in this way they would get prepared (married) to "lead" themselves the dance and the song at a later stage and obtain the role of more elderly men and social acceptance of the community. Likewise, engaged and single girls were initiated into another world, the world of the married woman through the customary procedure. The transition from the social role of the girl to the social role of the married woman was made by means of this custom and was always subject to the strict supervision of the elderly ones, who controlled the order and the hierarchy in this specific custom.

We can see from the above that the sergiani custom is a social and customary arena of initiation, control and negotiation of female identity, on one hand amongst the members of the community, so that the whole community would be aware of the social and hierarchical position of each woman, and on the other hand, amongst the women group, where each woman, according to her social position enjoyed social acceptance not only on behalf of other women but also on behalf of the whole community watching the custom. According to Geertz (2003), "...initiation rites are means for the establishment of sexual identity..." (p. 96). Therefore, the sergiani custom, as an initiation rite, validates the female identity and the role of the woman within the social context. An identity that is not fixed and consolidated, but keeps changing according to the social status, and this indicates the fluidity of the female social identity within the society. Moreover, the sergiani custom conceals a call from women towards women, having dance as the place of production. A call that starts from the elderly women, with a more powerful social position, towards younger women. This call through dance is a call for freedom from the household tasks (Spencer, 1985:158) and the patriarchal structure of the local society.

The above is validated by the religious dimension that was latent in the sergiani custom, since the whole ritual practice was framed by the religious factor. It is no coincidence that one of the spaces in which dances and songs of the custom were performed was the churchyard. This happens for two main reasons: firstly, because women wanted to validate themselves before the world (secular level) and before the church (sacred-divine level), the hierarchy and the position in the dance and as an extension of that their social position on a social level. Secondly, because the whole initiation and integration process needs the "sacred" validation. The transition from one level into another, the integration into a new social status needs to be done before sacred symbols and in sacred spaces, such as the church. Only through the divine testimony and validation can there be transition from a social status into another. As all passages from one social situation to another (baptism, wedding, funeral) need the divine validation, the same occurs with the sergiani custom, in order for this transition to be completed: this sacred/religious context is necessary in order for the women to achieve their social recognition and acceptance. As van Gennep (1960) states, two dimensions are the decisive ones, regardless the space and time when talking about passage ceremonies, those being: "...the sexual separation between men and women, and the magicoreligious separation between the profane and the sacred ..." (p. 189). The custom of sergiani presents both elements.

On a third level of data interpretation, as a rite, the sergiani custom... intensified the feeling of "we" and is a symbolic representation of the group identity..." (Pouchner, 2009:203). The inhabitants of the community gather in a common place (church or chorostasi, place reserved for 
dancing), using the custom as a means of reinforcing links amongst the group, one of which is matchmaking arrangements. In this way, women do not leave the community, they reinforce their identity climbing through the hierarchy levels of the family and confirm their determining role within the community. Gender relations are constantly subject to negotiation through which the female gender changes its social position and, accordingly, its connection with the same sex but also the opposite sex.

However, this also reveals structures through which the woman would constantly defy the patriarchal structure and male authority within the society. By controlling the patriarchal sovereignty in the community of Megala Kalyvia, the female gender would always find mechanisms to show resistance and renegotiate women's role, position and relation not only against the opposite sex, but also within women. Those mechanisms are triggered through customary and dance practices, such as the sergiani custom. They are mechanisms that lead to constant reflection and fluidity regarding gender relations and structures, reinforcing therefore the role and position of the woman, as she grows, both socially and biologically, within the framework of the family and the local society. The custom of sergiani is the "space" where this mechanism is triggered and dance is the "modality" through which women trigger this mechanism.

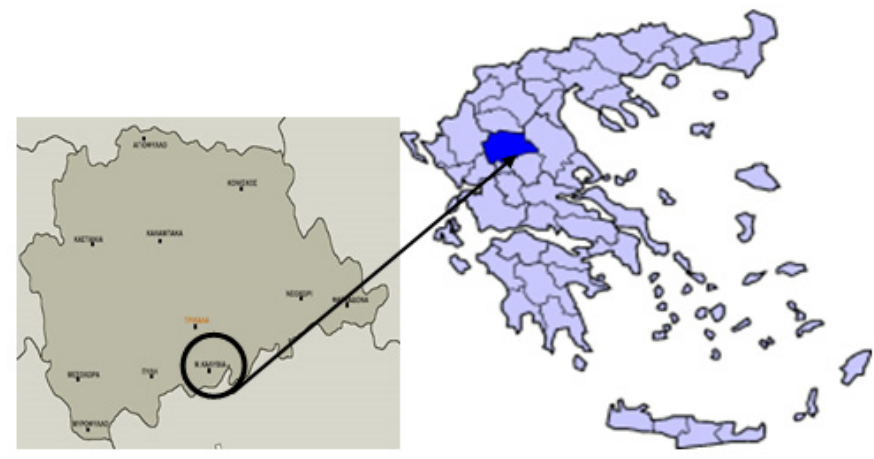

Map 1: Megala Kalyvia and its geographical position

Sources:

1)https://www.google.gr/search?q=\%CF\%87\%CE\%AC\%CF\%81\%CF\%84\%CE\%B7\%CF\%83+\%CE \%BC\%CE\%B5\%CE\%B3\%CE\%AC\%CE\%BB\%CF\%89\%CE\%BD+\%CE\%BA\%CE\%B1\%CE\%BB\%C F\%85\%CE\%B2\%CE\%B9\%CE\%B1+\%CF\%87\%CE\%B1\%CF\%81\%CF\%84\%CE\%B7\%CF\%82\&sour ce=Inms\&tbm=isch\&sa=X\&ved=0ahUKEwidm5zXoPvSAhVHuRQKHRi4BngQ_AUIBygC\&biw=1024\& bih $=467$ \#tbm=isch\&q=\%CE\%BD\%CE\%BF\%CE $\%$ BC $\%$ CF\%8C $\%$ CF $\% 82+\%$ CF $\% 84 \% C F \% 81 \% C E \%$ B9\%CE\%BA\%CE\%AC\%CE\%BB\%CF\%89\%CE\%BD+\%CF\%87\%CE\%AC\%CF\%81\%CF\%84\%CE\% $\mathrm{B} 7 \% \mathrm{CF} \% 82 \& *$ \&imgrc $=47 \mathrm{cjOoO}-1 \mathrm{Y} 6 \mathrm{XvM}$ :

2)https://www.google.gr/search?q=\%CF\%87\%CE\%AC\%CF\%81\%CF\%84\%CE\%B7\%CF\%82+\%CF $\% 84 \%$ CF\%81\%CE\%B9\%CE\%BA\%CE\%AC\%CE\%BB\%CF\%89\%CE\%BD\&source=Inms\&tbm=isch\& sa=X\&ved=0ahUKEwij5NGBoPvSAhWGbRQKHZSICMIQ_AUIBygC\&biw=1024\&bih=467\#imgrc=Vg Xc7KFKS2thyM:

\section{References}

Adshead, J. \& Layton, J. ([1983]1988). Dance history. A methodology for study. London: Dance Books.

Aggelis, V. (1987). Laography of lowland and components of the mountainous Thessaly. Customs - Traditions. Athens: Paraskeuopoulou editions.

Athanasiou - Dimopoulou, A. (2012). My village Agioi Anargiroi of Karditsa. Kardirsa.

Buckland, T. (1999). [Re]Constructing meanings: the dance ethnographer as keeper of the truth. In Theresa Buckland (Ed.), Dance in the Field: Theory, Methods and Issues in Dance Ethnography (pp. 196-207). London: Macmillan Press.

Bartenieff, I. et all. (1984). The potential of movement analysis as a research tool: a preliminary analysis. Dance 
Research Journal, vol. 16/3, 3-26.

Benesh, R., \& Benesh, J. (1977). Reading dance: The birth of choreology. London: Souvenir Press.

Bernand, H. R. (1994). Research methods in anthropology: Qualitative and quantitative approaches. Thousand, California: Sage.

Bertaux, D. (Ed.). (1981). Biography and society: The life history approach in the social sciences. Beverly Hills, California: Sage.

Chiotis, N. (1997). Megala Kalyvia. Our place and our world. Trikala: "Genesis".

Chiotis, N. (2005). Megala Kalyvia. Our place and our world. Volume II. Trikala: "Genesis".

Cohen, A. P. (1985). Informants. In R. Ellen (Ed.). Ethnographic research: A quide to general contact (pp. 223229). New York: Academic Press.

Crang, M., \& Cook, I. (2007). Doing ethnographies. London: Sage Publications.

Dimopoulos,K., Tyrovola, V. \& Koutsouba, M. (2009). The end of a ritual or the beginning of new social structures? The case of Bright Tuesday in the community of Lazarina, Karditsa, Thessaly. In Proceedings of the $23^{\text {rd }}$ World Congress on Dance Research. Cd-rom.

Dimopoulos, K., Tyrovola, V. \& Koutsouba, M. (2009). Ritual, symbolism and communication. The celebration of the Third day of Eastern in the community of Lazarina, Karditsa, Thessaly. In the Proceedings of $17^{\text {th }}$ International Congress on Physical Education and Sport. 22-24 May, pp. 73-74. Komotini, Greece.

Dimopoulos, K., Tyrovola, V. \& Koutsouba, M. (2010). Gender as determining factor of social structure. Sergiani in the community of Kranea Karditsa. In the Proceedings of $18^{\text {th }}$ International Congress on Physical Education and Sport. 21-23 May, p. 53. Komotini, Greece.

Dimopoulos, K., (2012). Space components and gender dance practices. The lowland and mountainous communities of Karditsa, Thessaly during the period 1920-1980. Master Thesis in the Department of Physical Education and Sport, National and Kapodistrian University of Athens.

Douglas, M. (1966). Purity and danger: An analysis of concepts of population and taboo. London: Routledge \& Kegan Paul.

Dwyer, K. (1982). Moroccan dialogues. Baltimore: John Hopkins University Press.

Farnell, B. (1999). It goes without saying-but not always. In Theresa Buckland (Ed.) Dance in the field: Theory, methods and issues in dance ethnography (pp. 145-160). London: Mcmillan Press.

Geertz, C. ([1973]2003). The Interpretation of Cultures. Paradellis, (transl.). Athens: Alexandria.

Giurchescu, A. (1999). Past and present in field research: A critical history of personal experience. In T. J. Buckland (Ed.). Dance in the Field: Theory, methods and issues in dance ethnography (pp. 41-54). London: Macmillan LTD.

Gkefou-Madianou, D. (1999). Culture and Ethnography. From the ethnographic realism to the cultural criticism. Athens: Ellinika Grammata.

Hanna, J.L. (1988). Dance, sex and gender. Signs of identity, dominance, defiance, and desire. Chicago: The University of Chicago Press.

Harrison, J.-E. ([1913]2006). Ancient Art and Ritual. Vicky Tatsi (ed.), Theodoros Siafarikas (transl.).Athens: lamvlichos.

Hutchinshon-Guest, A. (1984). Dance notation: The process of recording movement on paper. London: Dance Books.

Johnson-Jones, J. (1999). The choreographic notebook: a dynamic documentation of the coreographic process of kokuma dance theatre, an African-Caribbean dance company. In Theresa Buckland (Ed.), Dance in the Field: Theory, Methods and Issues in Dance Ethnography (pp. 100-109). London: Macmillan Press.

Kolonas, L. (2014). Rituals of Karagkounides and Religion. In the Proceedings of the $2^{\text {nd }}$ Panhellenic Ethnological Congress "Karagkounides of Thessaly in the circle of life". 7-9 September 2012, pp. (43-48). Municipality of Pyli.

Koutsouba, M. (2005). Notation of dance movement. Athens: Propompos.

Kyriakidou - Nestoros, A. (1993). Oral History and Laography. In N. Skouteri - Didaskalou, K. Ntelopoulos, \& M. Kairi (eds.). Laographic Studies, II (pp. 252-261). Athens: Poreia.

Lange, R. (1976). Some notes on the anthropology of dance. Dance Studies, vol. 1, pp. 38-46.

Leach, E. R. (1976). Culture and communication. Cambridge: Cambridge University Press.

Lydaki, A. (2001). Qualitative methods of social research. Athens: Kastaniotis.

Magouliotis, A. (2010). Agnantero of Karditsa. Karditsa: Karditsa Press.

Nitsiakos, V. (2003). Constructing place and time. Athens: Odysseas.

Ntoulas, C. (2009). Greeks in general and Karagkounides more specific in Laography. In the Proceedings of the $1^{\text {st }}$ Panhellenic Ethnological Congress “Karagkounides of Thessaly". 11-13 September 2009, pp. (97-100). Municipality of Palamas.

Page, J. (1996). Images for understanding: movement notations and visual recordings. Visual Anthropology, vol. 8, pp. 171-196.

Pouchner, V. (2009). Theoretic Laography. Athens: Armos.

Rabinow, P. (1977). Reflections on fieldwork in Marocco. Berkeley: University of California Press. 
Robson, C. ([1993]2007). Real World Research. Michalopoulou (ed.), Kalyva, (transl.). Athens: Gutenberg.

Rousiakis, S. (2006). Traditional dance in Megala Kalyvia, Trikala. In Trikalina. Proceedings of the $7^{\text {th }}$ Symposium of the Trikala Studies. 11-13 November 2005 (pp. 495-548). Trikala: F.I.L.O.S. Trikala.

Sklar, D. (1991). On dance ethnography. CORD Dance Research Journal, 23/1, pp. 6-10.

Spencer, P. (1985). Dance as antithesis in the Samburu discourse. In Paul Spencer (ed.), Society and the Dance. The social anthropology of process and performance (pp. 140-164). London: Cambridge University Press.

Schwaiger, E. (2012). Ageing, Gender, Embodiment and Dance. Finding a Balance. UK: Palgrave Macmillan.

Tegopoulos-Fitrakis (1990). Greek Dictionary. Athens: Armonia.

Tyler, S. (1986). Post-modern ethnography: From document of the occult to occult document. In J. Clifford \& G. Marcus (eds.). Writing Culture: The Poetics and Politics of Ethnography, pp.122-140.

Tyrovola, V. (1994). The Dance 'sta 3' in Greece. Structural and typological approach. Phd Thesis. Athens: Musical Department, National and Kapodistrian University of Athens.

Tyrovola, V. (2001). The Greek Dance. A different approach. Athens: Gutenberg.

Tyrovola, V. (2013). Dance issues A'. About dance... seven hypotheses for the science, art and the form of dance. Athens: V.K. Tyrovola.

Tziamourtas, Z. (2003). Laographic gallery of Karagkounides. Karditsa: Exarchos.

Tziamourtas, Z. (2006). The lingual treasure of Karagkounides. Karditsa: Exarchos.

van Gennep, A. (1960). The rites of passage. Chicago: The University of Chicago Press.

van Zile, J. (1985/1986). What is the dance? Implications for dance notation. Dance Research Journal, vol. 17/ $2, \&$ vol. $18 / 1$, pp. $41-47$.

van Zile, J. (1999). Capturing the dancing: Why and how? In Theresa Buckland (Ed.) Dance in the field: Theory, methods and issues in dance ethnography (pp. 85-99). London: MacMillan Press. 